\title{
SUSTAINABILITY OF PROJECT RESULTS WORKSHOPS IN PRIMARY SCHOOL CONDITIONS IN SLOVAKIA
}

Eva FELIXOVÁ, Univerzita Konštantína Filozofa v Nitre, Slovenská republika Gabriel BÁNESZ, Univerzita Konštantína Filozofa v Nitre, Slovenská republika

Přijato: 17. 12. 2019 / Akceptováno: 15. 5. 2020

Typ článku: Teoretická studie

DOI: $10.5507 /$ jtie. 2020.008

Abstract: The national projects Workshop 1 and Workshop 2 were supposed to support polytechnical education at elementary schools in the Slovak Republic using the supplied material equipment. The aim of the paper is to analyze teaching aids that were distributed to selected elementary schools in terms of their application within the innovative state educational program. The paper presents how the given teaching aids can be applied in individual thematic units and how they meet the criteria set by the state educational program.

Key words: state educational program, Technics, teaching aids

\section{UDRŽATELNOSŤ VÝSLEDKOV PROJEKTU DIELNE V PODMIENKACH ZÁKLADNÝCH ŠKÔL NA SLOVENSKU}

Abstrakt: Pomocou národných projektov Dielne 1 a Dielne 2 malo dôjst' $k$ podpore polytechnického vzdelávania na základných školách $v$ Slovenskej republike pomocou dodaného materiálového vybavenia. Ciel'om príspevku je analyzovat' učebné pomôcky, ktoré boli distribuované na vybrané základné školy z hl'adiska ich uplatnenia v rámci inovovaného štátneho vzdelávacieho programu. Príspevok prezentuje ako sa dané učebné pomôcky dajú uplatnit'v jednotlivých tematických celkoch a ako splñajú kritériá stanovené štátnym vzdelávacim programom.

Kl'účové slová: štátny vzdelávací program, predmet technika, učebné pomôcky.

\section{1 Úvod}

Vývoj školstva na Slovensku za posledných takmer tridsat' rokov a transformačný proces výchovy a vzdelávania prešiel niekol'kými zásadnými zmenami. Výrazný vplyv na charakter edukačných procesov má vždy politické prostredie v ktorom sa realizujú. Prvá zmena obsahu technického vzdelávania po roku 1989 sa uskutočnila z dôvodu zrušenia ideologického režimu školstva. Druhú vel'kú zmenu priniesol projekt Milénium, ktorý mal 
slúžit ako ideové východisko pri koncipovaní novej legislatívy. Tretím krokom smerom $\mathrm{k}$ vel'kej zmene a dôvodom kurikulárnej reformy 2008 bolo celoeurópske reformné úsilie začiatku 21.storočia. Táto školská reforma ale výrazným spôsobom negatívne zasiahla do technického vzdelávania na základných školách. Táto reforma priniesla nasledovné zmeny. V prvom rade sa zmenil názov predmetu $\mathrm{z}$ technickej výchovy na predmet technika. Druhou zmenou a výrazne negatívnou bola redukcia počtu hodín. Podl’a reformy sa mala učit len $0,5 \mathrm{~h} /$ týždenne $\mathrm{v}$ siedmom a ôsmom ročníku. Po určitom čase upresnením ministerstva sa mala učit' len jedna hodina techniky, pričom nezáležalo na tom v ktorom ročníku druhého stupňa základnej školy. Po určitom čase, konkrétne po siedmich rokoch v roku 2015 vstúpil do platnosti inovovaný štátny vzdelávací program, ktorý znovu zaviedol predmet technika po jednej hodine týždenne od piateho do deviateho ročníka. Súbežne s touto pozitívnou zmenou sa realizovali dva projekty, ktorých úlohu malo byt' podporit' polytechnické vzdelávania na základných školách, konkrétne predmetov technika, biológia, chémia a fyzika. Išlo o projekty „Podpora profesijnej orientácie žiakov základnej školy na odborné vzdelávanie a pripravu prostredníctvom rozvoja polytechnickej výchovy zameranej na rozvoj pracovných zručností a práca s talentami. “ (skrátene Dielne 1) a projekt Podpora polytechnickej výchovy na základných školách (skrátene Dielne 2).

Základnou myšlienkou projektu Dielne 1 bol rozvoj pracovných zručností a z toho vyplývajúca podpora profesijnej orientácie žiakov ZŠ na odborné vzdelávanie a prípravu. Rozvoj pracovných zručností žiakov bol prostredníctvom tzv. „polytechnickej výchovy“ implementovaný do priebehu vyučovania hlavne vo vzdelávacích oblastiach Človek a príroda: predmety biológia, fyzika, chémia a Človek a svet práce: predmet technika. V národnom projekte boli využité inovatívne formy a metódy výučby ako pripravit žiakov ZŠ na rozhodnutie o budúcom štúdiu či kariére. Projekt sa sústred’oval na vysoko aktuálne potreby vedomostnej spoločnosti, ako je príprava žiaka ZŠ na vykonávanie kvalifikovanej práce $\mathrm{v}$ hospodárstve a $\mathrm{v}$ odboroch, ktoré trh práce vyžaduje a kde žiak nájde svoje uplatnenie.

Projekt mal 3 nasledovné aktivity:

- $\quad$ Aktivita 1.1 Podpora polytechnickej výchovy žiakov ZŠ a d’alšie vzdelávanie pedagogických zamestnancov ZŠ v polytechnickej výchove.

- $\quad$ Aktivita 2.1 Podpora profesijnej orientácie žiakov ZŠ na odborné vzdelávanie a prípravu zavedením nástroja pre identifikáciu potenciálu orientácie žiakov ZŠ na OVP.

- $\quad$ Aktivita 3.1 Práca s talentami na ZŠ a SOŠ prostredníctvom realizácie a účasti na odborných sút’ažiach v OVP.

Na projekt Dielne 1 nadväzoval d’alší úspešný projekt Podpora polytechnickej výchovy na základných školách, ktorý umožnil rozšírit' skupinu podporených základných škôl a mal snahu zatraktívnit' a zvýšit' kvalitu vyučovacieho procesu v predmetoch zameraných na polytechnickú výchovu (Horecká, G. - Omachel, 2016).

Ciel’om tohto projektu bolo zvýšenie záujmu žiakov základných škôl o predmety zamerané na polytechnickú výchovu, rozvoj pracovných zručností žiakov hlavne v oblastiach vzdelávania predmetov fyziky, techniky, biológie a chémie a $z$ toho vyplývajúca podpora profesijnej orientácie žiakov ZŠ na odborné vzdelávanie a prípravu.

Prioritou aktivít projektu bolo skvalitnit' a zatraktívnit' vyučovací proces prostredníctvom vybavenia odborných učební chémie, fyziky, biológie, techniky s využitím moderných metód a foriem vzdelávania, aby mohla byt' uskutočnená obsahová prestavba vzdelávania 
na ZŠ a pripravit’ tak absolventa pre aktuálne a perspektívne potreby trhu práce (Horecká 2016).

Na projekt Dielne 1 nadväzuje d’alší národný projekt Podpora polytechnickej výchovy na základných školách, ktorý umožnil rozšírit’ skupinu podporených základných škôl a mal snahu zatraktívnit' a zvýšit' kvalitu vyučovacieho procesu v oblastiach zameraných na polytechnickú výchovu (Marušíncová, 2019).

Ciel'om národného projektu bolo zvýšenie záujmu žiakov základných škôl o predmety zamerané na polytechnickú výchovu, rozvoj pracovných zručností žiakov hlavne $\mathrm{v}$ oblastiach vzdelávania predmetov fyziky, techniky, biológie a chémie a $\mathrm{z}$ toho vyplývajúca podpora profesijnej orientácie žiakov ZŠ na odborné vzdelávanie a prípravu. Prioritou aktivít národného projektu bolo skvalitnit' a zatraktívnit' vyučovací proces prostredníctvom vybavenia odborných učební chémie, fyziky, biológie, techniky s využitím moderných metód a foriem vzdelávania, aby sme mohli uskutočnit' obsahovú prestavbu vzdelávania na ZŠ a pripravit’ absolventa pre aktuálne a perspektívne potreby trhu práce (Klačko. 2016)

\section{Uplatnenie učebných pomôcok $\mathrm{z}$ projektu Dielne $2 \mathrm{v}$ inovovanom štátnom vzdelávacom programe}

V našom príspevku pre posúdenie využitia dodaných učebných pomôcok použijeme metódu analýzy (Silverman, 2005). Dané učebné pomôcky budú analyzované z pohl'adu ich využitia $\mathrm{v}$ reálnej praxi.

Tabulka č. 1: Rozdelenie tematických celkov podl’a ročnikov.

\begin{tabular}{|c|c|}
\hline ročník & tematický celok \\
\hline \multirow{3}{*}{5.} & Človek a technika \\
\hline & Človek a výroba v praxi \\
\hline & Úžitkové a darčekové predmety \\
\hline \multirow{5}{*}{6.} & Človek a technika \\
\hline & Grafická komunikácia v technike \\
\hline & $\begin{array}{l}\text { Technické materiály a pracovné postupy } \\
\text { ich opracovania }\end{array}$ \\
\hline & Elektrická energia, elektrické obvody \\
\hline & Jednoduché stroje a mechanizmy \\
\hline \multirow{4}{*}{7.} & Grafická komunikácia v technike \\
\hline & $\begin{array}{l}\text { Technické materiály a pracovné postupy } \\
\text { ich opracovania }\end{array}$ \\
\hline & Stroje a zariadenia v domácnosti \\
\hline & Svet práce \\
\hline \multirow{4}{*}{8.} & Elektrické spotrebiče v domácnosti \\
\hline & Technická elektronika \\
\hline & Technická tvorba \\
\hline & Svet práce \\
\hline \multirow{4}{*}{9} & Bytové inštalácie \\
\hline & Strojové opracovanie materiálov \\
\hline & Tvorivá činnost' \\
\hline & Svet práce \\
\hline
\end{tabular}


Inovovaný štátny vzdelávací program, ktorý vstúpil do platnosti v roku 2015 bol rozšírený do piatich ročníkov základnej školy od 5. do 9. ročníka. Tematické celky sú po ročníkoch rozvrhnuté podl'a tabul'ky 1 .

V týchto tematických celkoch sa dodané učebné pomôcky môžu uplatnit'. V rámci projektu boli na jednotlivé školy dodané sady učebných pomôcok, náradia a nástrojov pre techniku. Išlo o (č́sla uvedené v zátvorkách reprezentujú ročník, v ktorom sa daná učebná pomôcka, sada dá uplatnit'): Hlukomer (5), Súprava mini eko vodíkové autíčko (5, 9), Súprava základných dielenských meradiel pre základné školy $(5,6,7,8,9)$, Súprava základného dielenského ručného náradia s príslušenstvom $(5,6,7,8,9)$, Nákova s príslušenstvom ( 6 , 7), Stavebnica na obrábanie dreva a kovu (5, 9), Zverák s príslušenstvom $(5,6,7,8,9)$, Micro-spájkovačka s príslušenstvom $(8,9)$, Vzorkovnica materiálov $(6,7)$, Súprava na nácvik pravouhlého premietania (-), Súprava akumulátorových skrutkovačov $(6,7,8,9)$, Teplovzdušná pištol' s príslušenstvom $(7,8,9)$, Nožnice na strihanie plechu s príslušenstvom (7), Sada nástenných tabúl' pre polytechniku $(8,9)$, Zostava pre elektrinu a magnetizmus $(8,9)$, Univerzálny merací prístroj na elektrinu $(8,9)$, Elektrodemonštračná sada $(8,9)$, Modely prierezov motorov (7), Merač spotreby elektrickej energie (8), Súprava základného náradia pre elektroniku $(8,9)$, Demonštračný model alternátora (9), Súprava o zdrojoch obnovitel'nej energie $(5,8,9)$, Vodoinštalačné zariadenie v kufríku (9), Demonštračný model WC splachovača (9), Demonštračný model vodovodného sifónu (9).

\section{Diskusia}

Ako z uvedeného vyplýva, tak najviac používanou učebnou pomôckou v predmete technika sú sady ručného dielenského náradia, meradiel, spolu so zverákmi. Je to logické, nakol'ko zameranie predmetu podl'a inovovaného ŠVP má byt' založené predovšetkým na praktickej činnosti. Jeho náplň sa má cielene zameriavat' na zručnosti a návyky pre uplatnenie žiakov v d’alšom živote a v spoločnosti a je založený na tvorivej myšlienkovej spoluúčasti a spolupráci žiakov. Slabšou stránku v tejto sade ručného náradia čo do kvality je píla na železo, ktorá spravidla nevydrží ani prvých pät rezov. Jej plastové časti sa zlomia, čím sa stane nepoužitel’nou.

Rovnako pomerne široké uplatnenie má sada Aku skrutkovačov, ktoré sa dajú využit' jednak na vítanie otvorov a rovnako na utahovanie skrutkových spojov. Pri práci s drôtom ako technickým materiálom je možné ich rovnako využit' na navíjanie drôtu za účelom jeho d'alšieho spracovania.

Vel'mi dobrou pomôckou je stavebnica na obrábanie dreva a kovov. Ide o stavebnicu typu Unimat, ktorú je možné využit' v širokom spektre rôznych strojov. Pre piaty a šiesty ročník je možné zostavit' lupienkovú pílu, ktorou sa dajú vyrezávat' ozdobné predmety z tenkej preglejky. Širšie uplatnenie uvedená sada nachádza v 9. ročníku v tematickom celku Strojové opracovanie materiálov. V tomto prípade sa $z$ danej stavebnice dá poskladat' sústruh na drevo, kov, horizontálna fréza, vertikálna fréza alebo stojanová vítačka. 
Obrázok č. 1: Zostava stavebnice Unimat pre sústruh na kov.

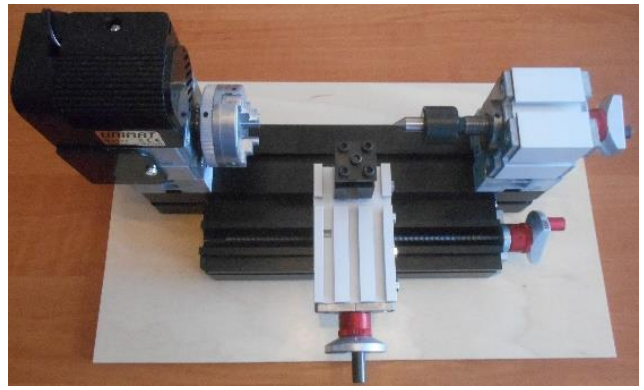

Učebné pomôcky určené pre základy elektrotechniky, technickej elektroniky majú tiež dobré uplatnenie. Ide hlavne o mikro spájkovačky, ktoré sa dajú využit' pri spájkovaní elektronických obvodov, respektíve sa dajú uplatnit' aj ako prostriedok na vypal'ovanie rôznych motívov pri práci dreveným materiálom. Elektronické stavebnice umožňujú nácvik zapojenia základných elektrických obvodov už v šiestom ročníku. Ich jedinou nevýhodou je nemecky písaný návod. Teda popis niektorých modulov stavebnice, napríklad na zapojenie jednoduchého rádiového prijímača, nie je v slovenskom jazyku. Vzorkovnica materiálov prezentuje niektoré technické materiály, sktorými sa žiak oboznamuje na hodinách techniky. Zastúpenie niektorých technickým materiálov mohlo byt' pestrejšie, hlavne ak ide o kovové materiály.

Vel'mi dobrou učebnou pomôckou, ktorá reprezentuje princíp činnosti netradičných zdrojov energie je Súprava o zdrojoch obnovitel'nej energie. Touto pomôckou je možné modelovat' veternú elektráreň, palivový článok a fotovoltajický článok. Uplatnenie tejto pomôcky je vhodné prakticky v každom ročník predmetu technika.

Absolútne nevhodne dodanou učebnou pomôckou je súprava na nácvik pravouhlého premietania. $\mathrm{V}$ prvom rade táto súprava svojím názvom nereprezentuje to, na čo je určená. Ide totiž o učebnú pomôcku, ktorá ukazuje princíp zobrazovania telies rôznych geometrických tvarov pomocou dvojice navzájom kolmých dvoch rovinných zrkadiel. $\mathrm{S}$ princípom zobrazovania telies na tri priemetne nemá nič spoločné.

Hlukomer, dodaný ako učebná pomôcka, má viaceré funkcie. Okrem toho že ukazuje na monitore čas a dátum, môže merat' hluk v miestnosti. Meranie je zobrazované ako číselná hodnota hluku v dB na monitore, alebo pomocou zeleného, oranžového alebo červeného smajlíka. Každej farbe zodpovedá určitá úroveň hluku, ktorá sa zobrazí zvýraznením daného smajlíka. Táto učebná pomôcka sa môže použit’ aj ako internetový vyhl'adávač (Táto učebná pomôcka bola dodaná ako monitor k počítaču, ktorý obsahuje nainštalovaný softvér pre popísané funkcie). Využitie tejto pomôcky je možné v tematických celkoch Človek a technika v 5. a 6. ročníku. Rovnako môže pôsobit' ako motivačný činitel' $\mathrm{v}$ školskej dielni a upozorňovat' na nadmerný hluk pri práci žiakov počas hodiny.

V našom príspevku sme popísali len niektoré vybrané učebné pomôcky, ktoré sa najlepšie hodili pre skvalitnenie predmetu technika. Respektíve tie, ktoré sme považovali pre predmet technika za nevhodné. 


\section{Záver}

Projekt Dielne 1 a Dielne 2 priniesol modernizáciu obsahu vzdelávania žiakov základných škôl v oblastiach Človek a príroda (biológia, fyzika, chémia) a Človek a svet práce (technika). Žiaci aj učitelia zapojených ZŠ majú možnost' lepšie sa zorientovat' $\mathrm{v}$ technických odboroch a v problematike profesijnej orientácie. Odborné učebne sú využívané aj po ukončení aktivít národného projektu, súčasne môžu byt' využívané ako normatív pre vybavenie d'alších odborných učební ZŠ. Národný projekt ako taký síce už skončil, no samotná podpora polytechnickej výchovy z týchto projektov je nesporná.

\section{Literatura}

Depešová, J., Tureková, I. (2014). Implementation model of teaching practice with the application of a videoconference system. In. ICETA 2014 - 12th IEEE International Conference on Emerging eLearning Technologies and Applications, Proceedings 7107554, pp. 91-96

ŠIOV (2016). Dielne 1. Štátny inštitút Odborného vzdelávania. Dostupné na: https://siov.sk/projekty/zrealizovane-projekty/tvorive-dielne-1/

ŠIOV (2016). Dielne 2. Štátny inštitút Odborného vzdelávania. Dostupné na: https://siov.sk/projekty/zrealizovane-projekty/tvorive-dielne-2/

Dostál, J. (2015). Inquiry-based Instruction and Teacher's cometences for its realization. In Journal of Technology and Information Education, 7(1):7-34. DOI: 10.5507/jtie.2015.001.

Hendl, J. (2016). Kvalitativní výzkum. Praha; Portál.

Horecká, G. - Omachel J. (2016). Záverečná konferencia národných projektov. Bratislava; Štátny inštitút odborného vzdelávania.

Horecká, G. (2017). Analytické posúdenie udržatel'nosti a dopadu projektov z hl'adiska širšich socioekonomických účinkov. Dostupné na: http://zsodborne.sk/wpcontent/uploads/2017/01/Kvalitat\%C3\%ADvne-vyhodnotenie-stavu-realizácie-NP-

Dielne-I.docx

Horecká, G. (2017). Národný projekt: Podpora profesijnej orientácie žiakov základnej školy na odborné vzdelávanie a prípravu prostredníctvom rozvoja polytechnickej výchovy zameranej na rozvoj pracovných zručností a práca $s$ talentami. Dostupné na. http://szodborne.sk

Horecká, G. (2015). Záverečná konferencia Národného projektu. Dostupné na: http://zsodborne.sk/wp-content/uploads/2017/01/Záverečná-konferencia_Dielne1.pptx

Klačko, M. (2016). Kvalitatívne vyhodnotenie stavu realizácie NP OPV - Podpora polytechnickej výchovy na ZŠ. Štátny inštitút odborného vzdelávania. Dostupné na: https://siov.sk/wp-content/uploads/2019/02/Manual-pre-organizaciu-novych-foriemziakov-ZS-na-povolanie.pdf

Lukáčová, D. (2010). Technology Education in Slovakia and School Reform. In. Journal of Technology and Information Education. 2(2):5-8 | DOI: 10.5507/jtie.2010.025

Marušíncová, M. (2017). Podpora polytechnickej výchovy na základných školách. Dostupné na: http://pvodborne.sk

ŠIOV (2015). Metodický materiál pre predmet technika. Dostupné na: https://siov.sk/wpcontent/uploads/2019/02/Metodicky-manual-pre-predmet-Technika.pdf

Silverman, D. (2005). Ako robit' kvalitatívny výskum. Bratislava; Pegas.

ŠIOV (2016). Záverečná konferencia národného projektku „Podpora polytechnickej výchovy na základných školách “. Dostupné na: http://pvodborne.sk/wpcontent/uploads/2017/01/Záverečná-konferencia_Dielne2.pptx 